\title{
Global decentralization policies for education and Tanzanian primary school principals' responses
}

\author{
Grace Rwiza \\ University of Alberta \\ rwiza@ualberta.ca
}

\begin{abstract}
Blackmore and Sachs' (2007) opinion that “educational reform needs to be seen within a broader context of restructuring in economic and social relations among the individual, the state and new modes of governance" (p. 1) is relevant for expressing the essence and influence of the global decentralization policies in Tanzania and elsewhere. The 1995 decentralization of the management of primary schools in Tanzania was the outcome of the World Bank's policies and the International Monetary Fund's conditions following the economic instabilities of the 1980s. Assuming that public systems are inefficient, autonomy in decision-making and competition are seen as means of achieving high quality and efficiency (Bonal, 2002; Carnoy, 1995; Martinez \& Garcia, 1996). The need for autonomy, external accountability and competition has created new managerial roles for school principals even though their core function is to lead instruction (Lingard \& Christie, 2003; Reitzug, West, \& Roma, 2008; Stewart, 2006). This study explores how principals in Tanzania are harmonizing these roles and is informed by political discourse analysis and decolonizing theories (Abdi \& Shultz, 2012; Blackmore \& Sachs, 2007; Dimmock \& Walker, 2005; Fairclough \& Fairclough, 2012; Nyerere, 1968; Wagenaar, 2011). Qualitative interpretive case study is also used to analyze the principals' experiences. The implementation of a borrowed culture in new contexts creates tensions; thus, the adoption of new roles in the context of decentralization creates conflicts and imbalances. Given that education is a public good, educational policies should be decolonized and separated from market influences.
\end{abstract}

\section{Introduction}

By 1995, all primary schools in Tanzania were decentralized to Local Government Authorities (LGAs), after the decentralization reform of 1994. Although decentralization was not 
a new policy in Tanzania, the 1994 reform was exceptional because it was shaped by foreign influences. The measure was aimed at bringing quality and efficiency into the education system through the devolution of power and the authority for decision making to lower levels including schools (Bonal, 2002; Carnoy, 1995; Kabagire, 2006). This re-organization was also intended to broaden the scope of participation and to eliminate inefficiency in the public school system by following business models, which emphasize the value of competition. In business models, competition is a pre-condition for quality and efficiency and thus, is centred on "discourses and practices subject to a neoliberal rationality" which underscore the primacy of the rule of the market (Bonal, 2002, p. 4). In the market context, schools are required to achieve stipulated market standards and to respond to clients' need to make choices among schools. Thus, school principals ${ }^{1}$ are being required to play new managerial roles. Given that leading instruction is the core function of principals (Leithwood, 2001; Lingard \& Christie, 2003; Reitzug, West \& Roma, 2008; Stewart, 2006); this study will explore how principals are harmonizing their roles without compromising the quality of instruction for the sake of the market.

By drawing from political discourse analysis and decolonizing theories (Abdi \& Shultz, 2012; Blackmore \& Sachs, 2007; Dimmock \& Walker, 2005; Fairclough \& Fairclough, 2012; Nyerere, 1968; Wagenaar, 2011) and qualitative interpretive case study, the consistency of the decentralization policy will be analyzed, and the influences shaping principals' actions will be established, respectively. These tasks will also involve the identification of the global actors' influence on the new conditions for the school principals.

\section{Theoretical framework}

Any discussion on education in the current context has to consider the influence of powerful global actors, who, due to their dominance in the world order, influence and shape the nature and direction of educational policy and practice (Crossley, 2000; Jones, 2007), without paying attention to the basics such as states' interests, the context of practice, and a policy's outcomes (Ball, 1993). Jones (2007) argues that

\footnotetext{
${ }^{1}$ Using of principals and head-teachers interchangeably.
} 
the global architecture of education is seen as a complex web of ideas, networks of influence, policy frameworks and practices, financial arrangements and organizational structures - a system of global power relations that exerts a heavy, even determining, influence on how education is constructed around the world. (p. 325)

Global actors use globalization as their tool for attaining their goals, creating frequent changes in institutions and systems. Such transformations are revealed not only in our economy and politics but also in our cultural relations. Given that power plays an integral role in this process, it subordinates individual, household, and states interests to global concerns (Rupert \& Solomon, 2006). Globalization involves economic growth; cultural, environmental, and social interdependencies; and the emergence of transnational financial, economic and political institutions. It also involves the increased flows of people, goods, ideas, money, and images across space (Blackmore \& Sachs, 2007).

Olssen (2004), in his seminal work, Neoliberalism, globalisation, democracy: Challenges for education, emphasizes on the complexity of globalization, which, at the policy level, requires national states to interact with international forms of capital. Therefore, globalization encompasses "neo-liberal" orthodoxy (open borders, floating exchange rates, abolition of capital controls, etc.), deregulation and liberalization of government policy, and [the] establishment of highly integrated transnational systems of alliances and privatization and marketization,[and Jalso the growth of private international authorities" (p. 241). The development of international authorities and their influential power, the exporting of ideas across borders in order to dominate other spaces, satisfying these authorities' economic demands, and increasing the role of the individual in the market, led to the need for deregulation, liberalization, and privatization, which are embedded in decentralization policies before being ultimately transferred to education systems.

Carnoy (2002) views globalization as a tool of global actors that transforms people's lives and practices, the production of goods and services, relations among nations, and local cultures. Carnoy (2002) also argues that financial forces, patterns of economic development, and market ideology are motivating globalization. In his view, for example, one way to attract financial capital is by reducing public spending on education while expanding investment in the 
private sector. At the same time global actors push for more and better education. This contradiction impacts the functioning of education systems particularly in developing countries.

The powerful global actors view public education sectors as inefficient, ineffective, and incapable of delivering quality services because of these sectors lack of competition. Thus, the advocates for decentralization believe that with increased decision-making authority, council and school officials can increase their flexibility and have more control over school development. These ideas are influenced by a model of private schools that are structured by the market and, thus, are able to respond to clients' needs, and public schools are expected to imitate this model. Under decentralization, such a model is expected to enhance competition by enabling parents to choose among schools and thus, to increase the quality of education (Carnoy, 2002, 1999; Wells \& Holme, 2005).

These ideas, along with Blackmore and Sachs' (2007) views that “educational reform needs to be seen within a broader context of restructuring in economic and social relations among the individual, the state and new modes of governance" (p. 1), are relevant for establishing the context of the essence of and the influences on the decentralization policies in Tanzania and elsewhere.

The measures of the World Bank (WB) and the International Monetary Fund (IMF) during the changes in the world economy in the 1980s and 1990s reveal these global actors' influence on education because their economic policies ultimately led to educational systems' restructuring. The WB and IMF during the 1980s and the 1990s gave economic aid (with conditions) to developing countries in order to help them rebuild their economies. The responses to this measure included the competitive-driven reforms that resulted in education institutional restructuring through decentralization (Carnoy, 1995) and that have shaped institutions, individuals, and their practises. This phenomenon reflects the power imbalance between the global actors who determine policies and the countries (particularly the developing countries), who practice these policies. Fundamentally, the recipients are victims of circumstances because some policies are incompatible with their context in terms of their social, economic and cultural aspects. Informed by critical political discourse theories (Agger; 2006; Fairclough \& Fairclough, 2012; Lukes, 2005) this study will analyze how power has influenced decisions and functions, on the one hand, and how policy as texts and discourse (Ball, 1993) has conditioned the nature and orientation of our educational institutions, on the other hand. The critical role of critical 
discourse analysis including political analysis is to position "power, conflict and struggle in the heart of its analytic approach" (Wagenaar, 2011, p. 158). Thus, by using this tool, the exploration will be "able to reveal the hidden contradictions and tensions that flow from structural power differentials in everyday policy initiatives" (p. 158).

The purpose of analysis in political discourse is to uncover hidden agendas by showing what has taken place, or as Wagenaar (2011) puts it, "to describe and explain, how and in what ways, the policy fails; what impediments and constraints of implementation will give [give] the policy the shape it eventually comes [has come] to have on the ground" (p. 166). Also, such analysis is intended to provide information on the problems of a complex social and economic context and the process of a policy's formulation and implementation (Fischer, 1995; Yanow, 2000). The analysis can either be on anticipated outcomes or on a policy's implementation results.

Political discourse analysis prioritizes argumentation; consequently, Fairclough and Fairclough (2012) believe that the "analysis of political discourse should centre upon analysis of practical argumentation" (p. 1). As argumentation deals with meaning, a researcher automatically is involved in interpretation. Basically, interpretive methods deal with meaning. Fay (1996) defines interprevitism "as the view that comprehending human behaviour, products and relationships consists solely in reconstructing the self-understandings of those engaged in creating or performing them" (p. 113).

Therefore, in order to establish how principals are harmonising their roles, in the context of global decentralization, the following three questions will guide the analysis.

1. How have the experiences of principals changed since the decentralization of the management of primary schools?

a. What are principals' explanations for the decentralization of the management of schools?

b. What local, national, regional and international policies that is framing principals' work and experiences of decentralization?

2. How are patterns of global policies evident in local policy and principals' experience and conceptualization of the organisation of schools?

a. To what extent do school leaders see themselves as autonomous? 
b. What influences do school leaders identify as being most important on their work in managing schools?

3. What strategies are principals using to harmonize their instructional and managerial roles in the context of the decentralization of education management, and how are these strategies being implemented?

\section{The role of school leadership and position of education}

A relationship exists between a leader's effectiveness and an organisation's efficiency. The leader's main role in organisations including schools is to contribute to the development and achievement of the organisational objectives. However, some authors challenge the tendency to associate leaders and organisational effectiveness, arguing that leaders do not always know their organisations well enough to be dependable (Lakomski, 2005; Spillane, 2006). In my opinion, particularly in Tanzanian schools, the leaders should be in charge of their organisations even if other organisation members also have some leadership roles.

Another key factor is the organisational environment. The context is crucial because it can either support or hinder the leader's functioning. A school leader has a role to play in the provision of quality instruction as one of his or her core functions. This role may include mobilizing the human resources (the teachers) and supervising, modeling, mentoring, and providing support as key activities in instructional development. In my view, this role needs support from a range of stakeholders and particularly from policy because of its nature as text and discourse (Ball, 1993). The nature of a policy, on the one hand, depends on the functioning and sensitivity of the policy makers, although, on the other hand, powerful actors might influence the policy's direction. For example, in the post- New Policy Management (NPM) era, especially after events such as those of September 11, 2001, the current situation has necessitated the review of existing policies to incorporate issues involving the common good. In some countries such as Canada, the governments have taken control of issues related to security, after having previously delegated them to the private sector ( $\mathrm{Pal}, 2010)$. When this tendency is replicated in education, one is tempted to reflect on what is taking place in our schools. How we are positioning schools and education has been my cardinal question. If education is a common good, are we achieving our goal, given what is expected from school leaders? Under 
decentralization, what are the lessons from school contexts, and what can be done to improve them?

Progressive educators suggest that leading instruction is the core function of principals. Lingard and Christie (2003) use Bourdieu's concepts of capital, habitus, fields and strategies to propose that the role of principals is to lead learning in schools even though educational policy has positioned principals as managers. "Capital” refers to the combination of principals" cultural, social, intellectual and symbolic attributes that are the basis for their actions, while "habitus" involves the leadership experiences gained through the apprenticeship of schooling and from educational management and leadership. A "field" represents the context of leadership. The competition for power defines the positions in the field and leads to the development of operational strategies. Lingard and Christie (2003) use the concept of "habitus" and "field" to discuss leadership, and also to assess habitus in relation to specific social structures. These authors also focus on "field" to discuss a principals' context; thus, they position a school as a "structured social space with its own properties and power relations, overlapping and interrelating with economic, political and other fields" (pp.319-320). In this framework, the key variable is the interplay between the practices of school principals with habitus and the principal's functioning in the conjunction of fields with different power structures, influences, and logics of practice. Focusing on Bourdieu's concepts separately and the interplay of fields, the authors suggest that, "[in] the concept of productive leadership, habitus is developed as a normative contribution for educational leadership, predicted upon the assumption that the focus of principal practices should be to lead learning” (p. 320). However, in the contemporary educational field, the ongoing educational reforms have created challenges for principals who share this assumption. School principals in Tanzania and elsewhere are now faced with multiple roles including instructional and management roles. My concern in this study is how primary school principals are harmonizing these roles.

The models of school leadership propose that the leaders of instruction should prioritize school "goals, the curriculum, instruction, and the school environment" (Stewart, 2006 p. 4). Thus, leading the school community towards academic excellence by teaching, supervising, modeling, mentoring and evaluating is seen as the core function of school principals.

In a market-oriented, decentralized education system, competitiveness is perceived as a means of producing quality. While competition involves public and private providers and 
requires schools to meet stipulated market standards, on the one hand, and to compete by providing a choice of schools, on the other hand, the current education reforms are geared to make educational providers (including teachers) accountable to their clients. The outcome is what Blackmore and Sachs (2007) calls an "institutional identity crisis" whereby schools "struggle to develop new profiles in order to maintain their legitimacy and existence in the eyes of the key stakeholders and the community as well as their distinctive contribution to education" (p. 1). This outcome is reflected in Tanzania, for example, when schools use any means to ensure their academic excellence. These means range from private tuition regardless of the time invested in teaching and learning during official hours, or the grade level (as even some Grade One students pay for private tuition), to extended teaching and learning after work or during holidays. While these practises may be seen as positive measures, one needs to harmonize them with the rationale for breaks or school vacations and accountability. Also, given the economic status of some parents, some students cannot afford to pay for private tuition and thus are left behind. Key questions are whether private tuition should replace remedial teaching or if the time expected for teaching and learning (the time on task) should be maximized so that private tuition is optional. In a way, this situation can be seen as the survival of the fittest, which is common in free market competition, whereas the goal of education systems should be to provide equal access and learning to everyone.

Additionally, Stewart (2006) argues that "decentralization also divert the principal's attention from the technical core of the school. Many school principals are so engrossed in the managerial and administrative tasks of daily school life, that they rarely have time to lead others in the areas of teaching and learning" (p. 6). In such a situation, the principals in the current education system are "politically squeezed between the expectations of classroom teachers, parents, the senior management team, and the members of the community" (p. 6). As a result, principals must work with a variety of stakeholders and maintain harmony among competing and conflicting demands from various interest groups (Hallinger, 2003). In Tanzania, for example, because of the schools' position and policy demands, principals have to respond to clients' demands from the schools, villages/mtaa (in urban settings), wards, councils, regions and the centre. Thus, the day-to-day school functions require head-teachers to carry out managerial roles.

\section{Background and essence of the of global decentralization policy in Tanzania}


Decentralization in Tanzania is not a new phenomenon, for decentralization existed in this country before colonialism. Also, after independence several decentralization efforts occurred. Supporters of decentralization emphasize that it provides "opportunities for grassroots participation in planning and local resource utilization" (Maro \& Mlay, 1979, p. 291). Based on this thinking, the main objective of the Arusha Declaration of 1967, for example, which established socialism and self-reliance, was "to give the people power over their own lives and their own development" (Nyerere, 1972, p. 1); thus, the decentralization model of 1972 in Tanzania aimed at implementing socialism and self-reliance, which were the focus of President Julius Nyerere's reforms (Nyerere was the first president of Tanzania formerly Tanganyika 1962-1985). Nyerere thought that, in order for the policies promoting socialism and self-reliance to be just, the local level must be fully involved in the planning and control of development because people are aware of their contextual problems and, thus, are able to prescribe more appropriate solutions than central administrators can. Such ideas were the foundation of the early decentralization efforts in Tanzania.

However, the second wave of decentralization in 1994 was exceptional because of the external influence on it. The reform was necessitated by the serious economic instability that had led to the deterioration of the economy by the end of the 1980s. Thus, all prior social and economic gains were affected including those in the education system. For example, the education sector experienced a shortage of teachers, teaching and learning materials, classrooms, and teachers' houses. Kabagire (2006), explains that

The Government responded to the economic crisis by embracing IMF-backed Structural Adjustment Programmes, (SAP), which were characterized by a transition period from the African socialist Ujamaa philosophy to an open economic system based on private enterprise, fiscal discipline, free trade and markets and a pluralistic political system. (pp. 5-6)

The above passage demonstrates the influence of the powerful global organizations that conditioned Tanzania to adopt externally driven policies. For example, the WB and IMF directives to developing countries, including Tanzania, required the reduction of public expenditures, competitive exchange rates, trade liberalization, and privatization (Abdi, 2002; Galabawa, 2001; Peet \& Hartwick, 2009; Robertson, Novelli, Dale, Tikly, Dachi, \& Alphonce, 1997; Shivji, 2006). These policies (the product of the Washington Consensus Institutions) are 
centred on "discourses and practices subject to a neoliberal rationality" emphasizing the primacy of the rule of the market (Bonal, 2002 p. 4). These measures marked a major shift from centralized economic policies focusing on collectivity, to decentralized policies focusing on the individual. Basically, such policies negate the communal elements in most African societies.

Because of the close relationship between the economy and the education system, the economic changes influenced educational policies, and thus, Tanzania began to implement liberalization policies. Therefore, the devolution and privatization as decision making levels (Lauglo, 1995; Rondinelli, Nelson, Cheema, 1984; Welsh \& McGinn, 1999) occurred in the Tanzania education system. According to the URT (1995), the authority to make decisions on school management was devolved to Local Government Authorities (LGAs) and schools while individuals and private organizations were allowed to establish and own schools. Decentralization by devolution was intended to make the schools more responsible to local communities in order to broaden the scope of participation, transparency, and new innovations. The rationale is that the schools and the community are aware of the nature of their problems and thus, problems can be solved more easily at this level than at any other level (Kabagire, 2006; Mmari, 2005; Nguni, 2005; Nyerere, 1972; URT, 1995; URT, 2001). Therefore, under decentralization by devolution, the responsibility for managing and administering education and training was given to the LGAs and heads of school and institutions. Also, because the authority to manage and administer education and training was given to the institutions, the change called for community participation and involvement in the management and administration of schools. This development led to an institutional arrangement that strengthened the school committees and made school heads answerable to them.

The implementation of decentralization by devolution gave increased power and authority over schools to committees that now have the power to make decisions on their school plans, purchase school materials, and supervise and follow up on issues related to school construction (URT, 2001). The school principal, as the secretary of the school committee, has to keep close ties with various educational stakeholders, including parents, school committee members, village governments, ward leaders, and other senior education managers. This role of keeping track of day-to-day activities requires school leaders to carry out managerial roles.

In essence, the business model and its inherent competition are associated with neoliberal philosophy and imply cultural borrowing through globalization processes. Scholars have 
suggested that such borrowing creates tensions when implemented in new contexts, especially when the new culture is not well-harmonised with the existing culture. Moreover, Dimmock and Walker (2005) argue that when business management and leadership models are transferred to education, "school principals become more isolated from teachers and students, and the core curriculum functions of the school, as they become office managers focusing on administrative issues and meeting accountability of the expectations of the central bureaucracies" ( p. 14). From this perspective, balancing instructional and management roles becomes a major challenge for principals.

\section{Context for the study}

The WB and IMF directed countries including Tanzania to implement Structural Adjustment Programs (SAPs) following the decades of economic crisis and instability (the 1970s and 1980s). As Carnoy (1995; 1999) explains, several educational measures such as competitive, financial, and equity- driven reforms were put in place in response to these changes. For example, competitive reforms attempted to achieve quality, efficiency, and effectiveness through the organisational reform of educational institutions by using decentralization policies (Bonal, 2002; Carnoy, 1995; Chubb \& Moe, 1990; Gropello, 2004; Martinez \& Garcia, 1996; Well \& Holme, 2005).

The reforms aimed at increasing economic efficiency in education and were perceived as a means for achieving economic development. This thinking has its roots in globalization. The nature of interconnectedness and the notion of sameness or uniformity in globalization (Dimmock \& Walker, 2005), causes changes in one region to be replicated in other regions. Thus, Tanzania as part of the global world, responded to the changes in the global economy that eventually influenced policy changes in education to enhance market freedom, competition, and efficiency. Carnoy (2002) summarises that, globalization, which is promoted by neo-liberalism, places education on an economic battlefield by emphasizing the need for competition and efficiency in the market. Therefore,

by decentralizing the management and finance of schooling, increasing competition in the education sector through greater school choice, including privatization and diminishing the power of teachers' unions, education systems can achieve large gains in efficiency 
and attract increasing private resources from families ready to pay for better schooling. (p. xvi)

However, the whole decentralization process creates some contradictions in practice. For example, scholars suggest that leadership is closely related to societal culture. Dimmock and Walker (2005) argue that "leadership is a socially bounded and constructed process. Values, thoughts and behaviours that are the essence of leadership are social and interactive processes; consequently, they are culturally influenced" (p. 12). The authors view culture as the "enduring sets of values, beliefs and practices that distinguish one group of people from another" (p. 13), and show the relationship between leadership and culture by citing Western societies that associate leadership with particular skills. On the other hand, globalization enforces similar policies and practices across political, cultural and geographical boundaries and supresses local cultures while enforcing the adoption of new cultures. A less rigid form of globalization would have to recognize the influence of local cultures on the future development of educational leadership (Dimmock \&Walker, 2005). Thus, the egalitarian principles which are meaningful to African societies would be preserved in educational policies for school leadership.

\section{Neo-liberalism and re-colonization}

Drawing from critical political discourse and de-colonizing theories where the question of power is central, and also given the scope of globalization, one is likely to confirm that the functioning of school principals has been influenced by powerful global actors involved in a form of re-colonisation. This influence has exposed principals to market forces under the umbrella of New Public Management (NPM - competition, quality and efficiency), which is a product of neo-liberal democracy. Thus, the policies of the IMF and the WB have shaped the new roles of head-teachers.

The influence of global actors on the decisions of local agents and the functions of principals can be explained by using political discourse analysis (Fairclough \& Fairclough, 2012), Lukes' (2005) definition of power, and Fairclough \& Fairclough's (2012), ideas on the "power behind discourse," which are consistent with Lukes' ideas, particularly those on the third radical dimension of power. As a specific type of power, "power over" is revealed when powerful actors constrain the choices of others by compelling them or securing their compliance 
in a manner that prohibits them from living as their own nature and judgement direct (Fairclough \& Fairclough, 2012; Lukes, 2005). The local agents' decisions reflect the influence of the power inherent in the decentralization policy and its implications for the education system and contextual leadership. In this context, Ball's (1993) conception of policy as discourse is also relevant. The effects of the decentralization policy clearly show the power of policy in shaping our world, particularly on how global actors influence local actors and policy implementers.

The above trend and the context of 1980s can serve as a blueprint for post-colonialism (Wright, 2012). In such a situation, the colonised countries continue to live with colonialism's residual effects (Abdi \& Shulttz, 2008; wa Thiongo, 1986; Wright, 2012). This result can also be explained by the rise of Euro-American hegemony after the fall of the Soviet empire in the 1980s, and the belief that the West is superior to the East. This line of thinking has led to different kinds of re-colonization (Abdi \& Shultz, 2012) including the re-colonization of the mind, or how people think. Thus, through globalization, neo-liberalism is dominating the world. This development is the essence of decentralization, the context for school principals that this study is exploring.

Harvey (2005) defines "neo-liberalism" as "a theory of political [and] economic practices that proposes that human wellbeing can be well developed by liberating individual entrepreneurial freedoms and skills within an institutional framework characterised by strong private property rights, free markets, and free trade" (p. 2). The rule of the market and the centrality of the individual give neo-liberalism its close relationship with liberal democracy. Also, the dominance of neo-liberal ideas after the fall of the Eastern bloc, their quick spread, and their wide media coverage have been due to the assumption of their superiority. Thus, neoliberalism basically is another form of colonialism in a post-colonial context. For instance, in the context of globalization, the flow of ideas and information dilutes the concept of national boundaries, so that neo-liberal ideas are likely to penetrate into domestic policy-making processes and to turn social policy decisions into the "result of cultural imperialism exercised by international agencies that have imposed a "neo-liberal agenda" (McNamara, 2007 p. 66).

This unidirectional trend of power indicates the power imbalances among agencies and the domination of some agencies over the others. Domination is basically structural because “peoples' everyday lives are affected by larger social institutions such as politics, economics, culture, discourse, gender and race" (Agger, 2006, p. 4). The decentralization educational reform 
is linked to globalization, which has its roots in the discourse and policies of neo-liberalism (Apple, 2001; Well \& Holme, 2005), and the countries that have chosen a decentralization policy have been “often taken as evidence for globalization's effect on educational policy” (Folwer, McGinn, Scribener, Layton \& Schugurensky, as cited in McNamara, 2007, p. 61). In essence, a close relationship exists between the development of educational decentralization and economic restructuring, a relationship that Carnoy (2002) calls the "twinned outcome of the new globalization" (p. xvi). Experience shows that the decentralization policies in different countries are similar because these policies are governed by similar external pressures, procedures, and organizational patterns (McNamara, 2007; Schugurensky, 2007). Thus, decentralization is basically a product of neo-liberal reform.

\section{Nature and scope of decentralization and Tanzania's policy response to globalization}

Carnoy (1995) and Welsh and McGinn (1999) suggest that the decentralization of the management of education involves the devolution of authority for decision-making from the higher to the lower levels including schools. Basically, decentralization shifts the location of the schools' governors from the apex to the base of the pyramid (Welsh \& McGinn, 1999).

Although centralized system of administration has the advantage of promoting unity by controlling disintegration, this system has been criticised for overlooking individual initiative. Hayek (1944) promotes the value of individualism and competition. He suggests that, because we have difficulty in accommodating the needs of our entire society, the individual should be the judge of all his goals, and within clear limits, his actions should be directed by his own views. To Hayek, competition is a guide for an individual's efforts.

Gropello (2004), McNamara (2007), and Rondinelli et al. (1984) suggest four levels of the transferring of decision making and authority under decentralization: de-concentration, where the devolution of authority is directed to other administrative levels of a ministry; delegation, where authority for public education is delegated to representatives of the minister at other levels; devolution, which transfers authority to elected bodies; and the shift of authority to private entities or individuals, or privatization.

Decentralization in Tanzania is a familiar system. For example, decentralization was used as an important tool when the country was implementing Socialism and self-reliance. In this 
process Nyerere (1972) emphasized people's involvement in the decision-making processes. However, the 1972 decentralization was different from the 1994 decentralization because of the latter's external influence. The 1994 reforms were established in the context of the implementation of the SAP that was introduced in 1986. This program, intended to help the private sector of the economy, resulted in the Civil Service Reform Program (CSRP), which included the Local Government Reform. The Local Government Reform aimed at decentralizing government functions, responsibilities, and resources to LGAs, as well as strengthening their capacity.

In general terms, several factors were used to justify the global decentralization policy. First, it advocates thought that the reform would benefit democracy and participation, even though genuine democracy involves more than just participation. Second, the collapse of the Western 'Keynesian consensus,' which had favoured strong, centralised governments, required the reformulation and reduction of the role of the central government, and thus, also an increase in the market's role (Welsh \& McGinn 1999, p. 27). Third, local groups were empowered by the shift towards market-based decision making while central governments and national sovereignty were weakened by the economic globalization and supranational organisations, respectively. Fourth, the public was dissatisfied with centralization, as the increase in the number of students and teachers exceeded the capacity of a centralized bureaucracy to maintain quality, and thus, the publics justified decentralization. Fifth, privatization, as one of the levels of decision making under decentralization, was seen as an alternative source of revenue after the governments' budget cuts to social services, including education. Sixth, many people believed that privatization uses resources effectively (Bonal, 2002; Harvey, 1990; Well \& Holme, 2005; Robertson, et al., 1997; Welsh \& McGinn). Finally, Kabagire (2006) reported that in developing countries, the justification for decentralization is "the need to establish working local governments that can deliver quality services to the people in a participative, effective and transparent way, where local authorities are directly accountable to the local people" (p. 9). However, given that in our current context, policies are combinations of national and global factors, and power is an integral factor, national interests, context of practice, and policy outcomes are not necessarily considered (Ball, 1993). Following the shift from centralized decision-making, the authority for managing primary schools was devolved to the LGAs, so that at the school level, school committees oversee the schools activities (URT, 1995; 2001). 


\section{Preliminary findings on principals' roles}

The emphasis on autonomy and competition under decentralization, on the one hand and, on widening the scope of participation, on the other hand, has introduced new roles for primary school principals. Thus, principals now have to take care of the demands and needs of a variety of stakeholders and must perform managerial roles. Without wanting to undermine other elements of leadership, I am concerned with the emphasis on "the centrality of instruction to the main business of the schools - student growth and development" (Ubben \& Hughes, 1997, p. 19).

The URT (1995) and ATA (2011) suggest that one of the purposes of education is to develop students' abilities so that individuals can achieve their personal aspirations and contribute positively to society. Also, in attaining national goals, schools play a fundamental role. The ability to carry out both strategic roles, to some extent, depends on the leaders' traits (Schein, 2010). The context also plays a key role in the functioning of leaders, because it may either support or hinder their functioning. Lingard and Christie (2003), show how contextual factors have changed principals' roles and conditioned them to be managers.

In the broadest sense, principals' instructional roles are basically related to the issues of teaching and learning. For example, in establishing goals, being models, creating a motivating work environment, and encouraging collaboration in order to create a high-performance learning community (Ubben \& Hughes, 1997). However, the business education model creates challenges for principals because service and business organisations are different. Although these organisations have same similar characteristics, schools,

in shaping and educating young people [,] go beyond the rudiments of business. Unlike business, schools are not primarily in existence to make [a] profit. They need equally to be concerned with processes and outcomes, many of which defy easy measurement or quantification. (Bottery, as cited in Dimmock \& Walker, 2005, p. 14)

Discussing the tensions created by the reforms to education, Blackmore \& Sacks (2007), argue that

Paradoxically, at a time when passion, creativity, and caring social relationships were necessary for individual and institutional survival, the tendency of educational reforms 
has been toward technical expertise, standardization and uniformity, products of both markets that produce risk and the new managerialism that seeks to manage it. (p. 2) According to Dimmock \& Walker (2005) and Blackmore \& Sacks (2007), the educational business model negates some professional elements and is in danger of compromising the teaching profession in particular and education in general.

In addition, Ball \& Maroy (2008) have shown how the competitiveness and interdependencies in the market context position schools in a complex system of school hierarchies. The National Association of Secondary School Principals (as cited in Stewart, 2006) notes that when secondary and primary school principals are placed in a market environment, their roles become extremely complex, because they range from legal experts, health service coordinators, fundraisers, public relations, parental matters experts to security officers. All these need managerial skills, while principals also are expected to implement their most important duty of instructional programs. The central point here is how can principals harmonize this wide range of new roles with their instructional role?

In Goodwin, Cunningham, \& Childress's (2003) study The changing role of the secondary principal, the interviewees identified 45 descriptors of principals' roles, which fall into four themes: role conflict, accountability conflict, autonomy conflict and responsibility conflict. For responsibility conflict, the clash is between increased responsibility and the need for both professional and clerical assistance. Central to this category of conflict was the increased workload that confronts principals during the restructuring of schools.

While decentralization aims at increasing participation in decision making, the literature suggests that the success of school-based management, to a large extent, depends on the ability of the administrators at the district and school levels "to maintain the involvement of the community in decision making" (Wesh \& McGinn, 1999, p. 34). However, in some places there is poor involvement of communities in decision making although, in some areas there are reports on the successes associated to community involvement. Fundamentally, although findings from qualitative research have no external validity and thus, cannot be generalized, their strengths reside in the knowledge we gain from lived experience. That being said, the preliminary findings suggest that conflicts and imbalances exist among principals' roles.

The outcomes of educational reforms in many parts of Sub-Saharan Africa not only suggest conflicts and imbalances but also reveal a radical change in how the public sector is 
being administered and managed. Moreover, in Tanzania and other developing countries, "where government institutions were still in the process of formation and development, there was no fat to cut, so the reforms cut through to the bone and in cases deformed the public administration systems" (Mutahaba \& Kiragu, 2002, p. 48). Thus, in many African countries, the government's capacity to administer the education system has deteriorated.

Another important factor in the reforms in Tanzania has been the involvement of a range of stakeholders including the Development Partners, who have played a key role in educational reforms. Mmari (2005) reported that PEDP (2002-2006) was implemented by the government in collaboration with different stakeholders including "development partners, the WB and local communities" (p. 18). Moulton (2002) discusses the importance of acknowledging the significance of stakeholders in the process of policy making, particularly those involved in the negotiation of priorities in the context of crisis. Here, Moulton uses Bunwaree, Carroll \& Carroll's, (2007) concept of "technocratic policy making” (p. 155) implying a small group of skilled elite that dominates policy formation, and thus, limited successes. Hence, authors suggest a participatory consultative process for an effective reform for policy making.

Masue (2010) explored school committee's empowerment and autonomy, and suggested that, the current school committees have more responsibilities and autonomy. This was manifested through the "day-to-day running of the schools, community mobilization for school infrastructure development (classroom, teachers, houses, toilets and so on) as per the local priorities, procurement of school materials and control of pupils' discipline" (p. 109). The involvement of school committees was associated with big achievements of PEDP (2002-2006) in terms of enrolment and construction. The crucial point in this process is the position of the secretary of the school committee. With these achievements, the head-teachers had a key role in the whole process.

Although many nations have opted for decentralization, they have rarely paid enough attention to the challenges that are facing local actors including school leaders, and appropriate strategies for its success. There are areas that need attention for effective implementation of Dby-D, such as capacity-development of local actors (IIEP, 2010; URT, 2011). These concerns originate from "the increasing workload at local levels, [which] raise the question of sustainability and effectiveness" (URT, 2011, p. 387). The report suggests an urgent need for action, because the situation is likely to be serious since "the workload increases through new 
tasks ... and increased demands for accountability" (pp. 388-389). The Tanzania Education Sector Analysis was focusing on the context of decentralization and how actors for example at LGAs' levels are faced with an increased workload. The concern of this study is to go beyond the workload of actors (head-teachers are in the same context) and establish how they are harmonizing their instructional and managerial roles.

Given the complexities of todays' principals' roles in educational reforms, questions arise as to whether the definition of principals' role is adequate or if the principals' job it needs to be re-designed. New developments in leadership approaches are concerned with organisational culture, practice, and the social context of action (Lakomski, 2005). Such an orientation questions the causal link between leadership and practice, to the extent of suggesting the end of leadership. The assumption is that, by emphasizing leadership, we are expecting more than leaders can offer, given their own resources. The argument is based on the fact that organisational work involves many different people, and leaders are neither all-knowing nor always dependable. Thus, authors including Lakomski (2005), Robinson (2001) and Spillane (2006) recommend a leadership style such as distributed or disbursed leadership, which responds to situational and contextual factors. Distributed leadership occurs when leadership functions are shared by a number of people in an organization or when leadership originates from the interactions within a group. Lakomski (2005) observes that with distributed leadership, a leader is not detached from others and is embedded in task performance.

Distributed leadership can logically be associated with the objective, content, and approach of Nyerere's decentralization policy. In 1972, following the Arusha Declaration of 1967, Tanzania implemented policies involving socialism and self-reliance. This declaration's main objective was to give people power over their own lives and development, and decentralization was used to achieve this objective. Nyerere's (1972) concern was that "in order to make a reality of our policies of socialism and self-reliance, the planning and control of development in this country [Tanzania] must be exercised at [the] local level to a much greater [degree] than at present" (p. 1). At that time, all decisions were made at the centre. Nyerere believed that local people are aware of their problems and are more likely than central administrators to use their initiative to find solutions for their challenges, and that when power remains at the centre; problems are likely to remain unsolved. This line of thinking is similar to the ideas that justify the need for the distribution of leadership (Lakomski, 2005). However, 
distributed leadership aims at distributing functions so that each function can be effectively performed, but does not eliminate the influence of the market, which is not compatible with the teaching profession in particular and education in general.

In their interpretive study, Newton and Wallin (2013) explored the role of the teaching principal in Alberta and Manitoba by focusing on this role's moral and legal requirements. The principals in these provinces are expected in their position as instructional leaders to support student learning. The authors referred to Clarke and Stevens' (2009) definition of a teaching principal, as one who carries out the roles of teaching and administration. After exploring the constitution and how the two roles have affected the leadership practices of rural teaching principals, the authors called for policies that will guide administrators who need to carry out dual roles in smaller schools. As well, the authors noted that the teaching principals' methods for adapting to their new roles are a new development in the conceptualization of school principalship.

\section{Conclusion}

Global decentralization policies require school leaders to carry out managerial functions in addition to their core instructional roles. The literature on leadership under education reforms indicates that tensions exist between instructional leadership and administrative management roles. The way that principals in Tanzania are harmonizing their dual roles is the focus of this study. While decentralization aims at increasing quality and efficiency, the preliminary findings indicate that some managerial responsibilities are preventing school leaders from effectively carrying out their instructional roles, possibly because of the demands of decentralization, which

promotes autonomy and external accountability, on the one hand, and a business orientation and competition, on the other hand. Also, the use of the business model in education can be incompatible with the culture of the host society in general and the principals' profession in particular. The conflicts between individualism and egalitarian principles, the privileging of individualism in the business model, and the nature of the teaching profession are key issues in the decentralization process. Given that societal culture is a set of values, beliefs and practises that distinguish groups, and also given the need to avoid decentralization's tendency to create implementation tensions, the "local" culture must be considered when developing and 
implementing global decentralization policies (Dimmock \& Walker, 2005). For example, a deep understanding of the importance of the communal is necessary in order to develop appropriate policies for African societies. Also, given that powerful global actors are clearly influencing the whole decentralization process, which is a reflection of re-colonization, a critical dialogue between the global and the local actors is essential for achieving a mutual partnership in the process of global decentralization. Thus, in order to avoid implementation problems, the most appropriate policies are those that accommodate the needs of the host countries (Dimmock \& Walker, 2005). Particularly, when developing education policies, policy makers must be culturally sensitive enough to respect the integrity of indigenous cultures and, thus, to decolonize the whole process of education reform. 


\section{References}

Abdi, A. A. (2002). Culture, education and development in South Africa: Historical and contemporary perspectives. London: Bergin \& Garvey.

Abdi, A. A., \& Shultz, L. (2012). Recolonized citizenships, rhetorical postcolonialities: SubSaharan Africa and the prospects for decolonised ontologies and subjectivities. In V. Andreotti \& L. T. M. Souza (Eds.), Postcolonial perspectives on global citizenship education (pp. 158-171). New York, NY: Routledge.

Abdi, A., \& Shultz, L. (2008). Education for Human Rights and Global Citizenship: An Introduction. In Ali A. Abdi and Lynette Shultz (Eds.) Educating for Human Rights and Global Citizenship. Albany, NY: State University of New York Press

Agger, B. (2006). Critical social theories (2nd ed.). London: Paradigm Publishers.

Alberta Teaching Association. (2011). Teaching in Alberta: A teacher education learning resource. Edmonton: ATA.

Ball, S. J. (1993). What is policy? texts, trajectories and toolboxes. Discourse: Studies in the Cultural Politics of Education 13 (2), 10-17.

Ball, S. J., \& Maroy, C. (2008). School's logics of action as mediation and compromise between internal dynamics and external constraints and pressures. Compare: A Journal of Comparative and International Education, 39 (1), 99-112. Retrieved from http://dx.doi.org/10.1080/03057920701825544.

Blackmore, J., \& Sachs, J. (2007). Performing and reforming leaders, gender, educational change. Albany, NY: State University of New York Press.

Bonal, X. (2002). Plus ca change... the World Bank global education policy and the Post Washington Consensus. International Studies in Sociology of Education 12 (1), 3-22.

Bunwaree, S., Carroll, B. W., \& Carroll, T. (2007). Popular participation contentious policy areas: Education policy in Mauritius. Journal of Comparative Policy Analysis: Research and Practice 7(2), 155-176. London, UK: Routledge. Retrieved from http://www.tandfonline.com/loi/fcpa20 DOI 10.1080/13876980500116220.

Carnoy, M. (1995). Structural Adjustment and the changing face of education. International Labour Review 134 (6), 653-673.

Carnoy, M. (1999). Globalisation and education reform: What planners need to know? Paris: UNESCO. 
Carnoy, M. (2002). Foreword. In H. Daun (Ed.). Educational restructuring in the context of globalization and national policy. New York, NY: Routledge Falmer.

Chubb, J. E., \& Moe, T. M. (1990). Politics, markets and America's schools. Washington, DC: The Brookings Institution.

Crossley, M. (2000). Bridging cultures and traditions in the reconceptualization of comparative and international education, Comparative Education, 36 (3), 319-332.

Dimmock, C., \& Walker, A. (2005). Educational leadership: Culture and diversity. Thousand Oaks, CA: Sage Publications.

Fairclough, I., \& Fairclough, N. (2012). Political discourse analysis: A method for advanced students. New York, NY: Routledge Taylor and Francis Group.

Fay, B. (1996). Contemporary philosophy of social science: A multicultural approach. Oxford, UK: Blackwell.

Fischer, F. (1995). Evaluating public policy. Chicago: Nelson-Hall.

Galabawa, J. C. J. (2001, October). Developments and issues regarding Universal Primary Education (UPE) in Tanzania. Paper presented in Association for the Development of Education in Africa (ADEA) Biennial Meeting, Arusha - Tanzania.

Goodwin, R. H., Cunningham, M. L., \& Childress, R. (2003) The Changing Role of the Secondary Principal. NASSP Bulletin 2003 87: 26 DOI: 10.1177/019263650308763403.

Gropello, E. (2004). Education decentralization and accountability relationships in Latin America. Washington, DC: World Bank.

Hallinger, P. (2003). Leading educational change: Reflections on the practice of instructional and transformational leadership. Cambridge Journal of Education, 33 (3), 329-351.

Harvey, D. (2005). A brief history of neoliberalism. New York, NY: Oxford University Press. Hayek, F. A. (1944). The road to serfdom. Chicago, IL: The University of Chicago Press. International Institute for Educational Planning (IIEP) (2010). Schooling and decentralization: Patterns and policy implications in Francophone West Africa. Paris: UNESCO

Jones, P. W. (2007) Education and world order. Comparative Education, 43 (3), 325-337. Kabagire, A.I.R. (2006, December). Delivery of public services in a devolved system of governance: The Tanzanian experience. Paper presented to the 28th African Association for Public Administration and Management - Annual roundtable conference, Arusha, Tanzania 4th - 8th December 2006. 
Lakomski, G. (2005). Managing without leadership towards a theory of organisational functioning. Amsterdam, NL: Elsevier Inc.

Lauglo, J. (1995). Forms of decentralisation and their implications for education. Comparative Education, 31 (1), 5-29.

Leithwood, K. (2001).School leadership in the context of accountability policies. In International Journal of Leadership in Education 4 (3), 217-235.

Lingard, B., \& Christie, P. (2003). Leading theory: Bourdieu and the field of education leadership. International Journal of Leadership in Education, 6 (4), 317-333.

Lukes, S. (2005). Power: A radical view. Hampshire, UK: Palgrave Macmillan.

Maro, P. S., \& Mlay, W. F. I. (1979). Decentralization and the organization of space in Tanzania. Africa 49 (3), 291-301 doi: 10.2307.1159561, 2011.

Martinez, E., \& Garcia, A. (1996). What is Neoliberalism? Retrieved from http://corpwatch.org/article.php?id=376 November 27, 2011.

Masue, O. S. (2010). Empowerment and effectiveness of school committees in Tanzania (Master Thesis), University of Bergen, Norway. Retrieved from https://bora.uib.no/handle/1956/997/discover?field=subject\&fq=subject_filter:school\%5C $\% 20$ committees $\% 5 \mathrm{C} \% 7 \mathrm{C} \% 5 \mathrm{C} \% 7 \mathrm{C} \% 5 \mathrm{C} \% 7 \mathrm{CSchool} \% 5 \mathrm{C} \% 20$ committees\&fq=author_fil ter\%3Amasue $\% 2 \mathrm{C} \% 5 \mathrm{C}+$ orest $\% 5 \mathrm{C}+$ sebastian $\% 5 \mathrm{C} \% 7 \mathrm{C} \% 5 \mathrm{C} \% 7 \mathrm{C} \% 5 \mathrm{C} \% 7 \mathrm{CMasue} \% 2 \mathrm{C} \%$ 5C+Orest\%5C+Sebastian (2010-05-31).

McNamara, M. (2007). Assessing the globalization-decentralization nexus. Patterns of educational reform in Mexico, Chile, Argentina and Nicaragua. In S. Lee \& S. McBride (Eds.), Neoliberalism, state power and global governance, (pp. 61-76). Dordrecht, NL: Springer.

Mmari, D.M.S. (2005). Decentralization for service delivery in Tanzania. Paper presented at the conference on building capacity for the education sector in Africa - Oslo, Norway.

Moulton, J., Mundy, K., Welmond, M., \& Williamson, J. (2002). Education reform in SubSaharan Africa: Paradigm lost. Westport, CT: Greenwood press.

Mutahaba, G., Baguma, R., \& Halfani, M. (1993). Vitalizing African public administration for recovery and development. West Hartford, CT: Kumarian press.

Newton, P., \& Wallin, D. C. (2013). The teaching principal: An untenable position or a promising model? Alberta Journal of Educational Research, 59 (1), 55-71. 
Nguni, S. C. (2005).Transformational leadership in Tanzanian education: A study of the effects of transformational leadership on teachers' job satisfaction, organizational commitment and organizational citizenship behaviour in Tanzanian primary and secondary schools. (Doctoral dissertation). Nijmegen, NL: Rodbound University.

Nyerere, J. K. (1968). Freedom and Socialism: Speeches and Writing, 1965-67, London, UK: Oxford University Press.

Nyerere, J. K. (1972). Decentralization. Dar es Salaam: Government Printer.

Olssen, M. (2004). Neoliberalism, globalisation, democracy: Challenges for education. Globalisation, Societies and Education, 2 (2), 231-245. Doi: 10.1080/14767720410001733665.

Pal, L. S. (2010). Beyond policy analysis: Public issues management in turbulent times. (4th ed.). Toronto, ON: Nelson Education Limited.

Peet, R., \& Hartwick, E. (2009). Theories of development: Contentions, arguments and alternatives. New York, NY: The Guilford Press.

Reitzug, U. C., West, D. L., \& Roma, A. (2008). Conceptualizing instructional leadership the voices of principals. Education and Urban Society, 40 (6), 694-714. 10.1177/0013124508319583 http://eus.sagepub.com hosted at http://online.sagepub.com.

Robertson, S., Novelli, M., Dale, R., Tikly, L., Dachi, H., \& Alphonce, N. (1997). Globalisation development and education: Ideas, actors and dynamics. Bristol, UK: Department for International Development.

Robinson, V. M. J. (2001). Embedding leadership in task performance. In K. Wong \& C. W. Evers (Eds.), Leadership for quality schooling (pp. 90-102). New York, NY: Routledge Falmer.

Rondinelli, D. A., Nelson, J. R., \& Cheema, G. S. (1984). Decentralisation in developing countries: a review of recent experience. Washington, DC: World Bank, Staff Working.

Rupert, M. \& Solomon, M. S. (2006). Globalization \& international political economy: The politics of alternative futures. New York, NY: Rowman \& Littefield publishers, Inc.

Schein, E. (2010). Organisational culture and leadership (4th ed.). San Francisco, CA: John Wiley and Sons.

Schugurensky, D. (2007). The higher education restructuring in the era of globalization: Towards a heteronomous model. In R. Arnove \& C. Torres (Eds.), Comparative education: The 
dialectic of global and the local (3rd ed.). (pp. 257-276). Plymouth, UK: Rowman \& Littlefield publishers, Inc.

Shivji, I. G. (2006). Let the people speak Tanzania down the road to Neo-liberalism. Dakar: Council for the Development of Social Science Research in Africa.

Spillane, J. P. (2006). Distributed leadership. San Francisco, CA: Jossey-Bass.

Stewart, J. (2006). Transformational leadership: An evolving concept examined through the works of Burns, Bass, Avolio, and Leithwood. Canadian Journal of Educational Administration and Policy, 54, 1-29.

Ubben, G. C., \& Hughes, L. W. (1997). The principal: Creative leadership for effective schools (3rd ed.). Boston, MA: Allyn \& Bacon.

United Republic of Tanzania (1995). Education and Training Policy. Dar es Salaam: Adult Education Press.

United Republic of Tanzania (2002). Primary Education Development Program I (2002-2006). Dar es Salaam: BEDC.

United Republic of Tanzania (2011). Tanzania education sector analysis beyond primary education: The quest for balanced and efficient policy choices for human development and economic growth regional bureau for education in Africa. Dar-es-Salaam: Adult Education Press.

wa Thiongo, N. (1986). Decolonising the mind: The politics of language in African literature. London: James Curry.

Wagenaar, H. (2011). Meaning in action interpretation and dialogue in policy analysis. New York, NY: M.E. Sharpe.

Wells, A. W., \& Holme, J. J. (2005). Marketization in education: Looking back to move forward with stronger critique. In N. Bascia, A. Cumming, A. Datnow, K. Leithwood \& D. Livingstone (Eds.), International Handbook of Educational Policy, 19-51 @ 2005. Great Britain, GB: Springer.

Welsh, T., \& McGinn, N. F. (1999). Decentralization of education: Why, when, what and how? Paris: UNESCO.

Wright, C. (2012). Postcolonial cosmopolitanisms: Towards a global citizenship education based on divisive universalism. In V. Andreotti \& L. M. T. M. Souza (Eds.), Postcolonial perspectives on global citizenship education (pp. 47-67). New York, NY: Routledge. 
Yanow, D. (2000). Conducting interpretive policy analysis. Thousand Oaks, CA: Sage Publications. 